\title{
FROM FORESTRY TO PROTECTED AREA AND ECOSYSTEM MANAGEMENT: ORGANISATIONAL CHANGE IN SAINT LUCIA, WEST INDIES
}

\author{
Michael R. Appleton ${ }^{1,3,}{ }^{,}$, Adams Toussaint ${ }^{2}$ and Jennifer C. Daltry ${ }^{3}$
}

Corresponding author: mappleton@globalwildlife.org

${ }^{1}$ Global Wildlife Conservation, PO Box 129, Austin, TX 78767, USA.

${ }^{2}$ Saint Lucia Forestry Department, Union Forestry Complex, Union, Castries, Saint Lucia.

${ }^{3}$ Fauna \& Flora International, David Attenborough Building, Pembroke Street, Cambridge CB2 3QZ, UK.

\begin{abstract}
While global expectations of what protected areas should deliver are evolving (e.g. through the Aichi Targets and the UN Sustainable Development Goals), little attention has been paid to how government protected area agencies can adapt and improve their performance accordingly. The remit of the Saint Lucia Forestry Department has gradually extended from production forestry to, inter alia, protected area management, wildlife research and conservation, watershed management, tourism and environmental education. In 2014, in response to a widespread consensus on the need to update its ways of working, the Department initiated a participatory process of strategic planning and organisational change, comprising: (1) Organisational review and capacity needs assessment; (2) Development of a new strategic plan and corresponding restructuring of the organisation; and (3) Institutionalisation of the plan. This generally successful process provides important lessons with potentially wider application on 'change readiness', leadership, capacity, communication, participation, and the value of 'quick wins'. While further work is needed on capacity development and full institutionalisation of the changes, the Forestry Department is now better able to articulate its roles and needs and to ensure long-term conservation and sustainable use of Saint Lucia's globally important biodiversity, both inside and outside its protected areas. We call for further studies and initiatives on organisational change in government agencies responsible for protected areas and biodiversity conservation.
\end{abstract}

Key words: Caribbean, forestry, management, organisational change, participatory planning, protected areas, strategic planning

\section{INTRODUCTION}

Organisational change is simply defined by Dawson (2003) as "new ways of organizing and working". Among the abundant literature on the topic, far less attention is given to the public sector than the private sector (Pick et al., 2015; Kuipers et al., 2013). In the forestry sector, a range of studies have addressed change management (e.g. World Bank, 2005; Durst et al., 2008; Spathelf, 2010), mainly in the context of shifting economic trends. Organisational change specifically related to agencies responsible for protected areas has received very limited attention (examples include Anon., 2014 from New Zealand and Colwell et al., 2014 from the USA), and the topic is addressed in only one short paragraph in the landmark publication of Worboys et al. (2015).
This apparent lack of attention to how protected area management agencies can adapt and improve is surprising, given the increase in the global number and coverage of protected areas (UNEP-WCMC \& IUCN, 2016) and the widening global expectations of what protected areas should deliver, articulated in Aichi Biodiversity Target 11 (Convention on Biological Diversity, 2010) and United Nations Sustainable Development Goals 14 and 15 (United Nations, 2015). The 'Promise of Sydney' (Sandwith et al., 2014), agreed at the 2013 IUCN World Parks Congress, includes "a commitment to transforming perspective, policy and practice to enhance protected areas as one of the best investments in our planet's and our own future" and includes dozens of recommendations under "twelve 
innovative approaches for transformative change". Translating these aspirations into real change and improvements in protected area management remains a challenge, however. In general, the protected area sector is under-resourced, lacks capacity, and is subject to frequent enforced changes resulting from budget cuts and political factors (Worboys, 2015). To address these issues and to meet the global standards defined for the IUCN Green List of Protected and Conserved Areas (IUCN and WCPA, 2016), protected area authorities need to be up-to-date, flexible, responsive and exemplars of good governance: characteristics not normally associated with typically centralised, bureaucratic government agencies.

This study documents a strategic planning and organisational change process in the Forestry Department (hereafter Department) of the Eastern Caribbean island of Saint Lucia, which was explicitly undertaken to strengthen this organisation's ability to rise to the new expectations and challenges of managing the protected areas and natural resources under its responsibility.

\section{THE SAINT LUCIA FORESTRY DEPARTMENT}

Saint Lucia is the second largest island of the Lesser Antilles, with an area of $616 \mathrm{~km} 2$ and a population of close to 167,000 . The Forestry Department was established in 1946 to manage timber production and maintain the mountainous Central Forest Reserve (now the country's largest protected area, IUCN Category II, 9,196 ha.) that protects the island's main water supplies. In the 1980 s, under the pioneering leadership of Gabriel 'Coco' Charles, the Department started expanding its remit to include watershed management, nature conservation, forest visitation, environmental education and community outreach. In response to climatic trends in the Eastern Caribbean (notably, lower and less predictable rainfall and more frequent storms), forestry work today mainly focuses on maintaining and restoring tree cover, protecting water courses and controlling erosion across the island, while timber production is now limited to small-scale harvesting for local community needs.

More than 70 per cent of Saint Lucia is forested and supports a rich diversity of wildlife, including the emblematic Saint Lucia parrot (Amazona versicolor), one of six country-endemic bird species, whose population has recovered from fewer than 100 to over 2,000 individuals since the 1950s. The forests also support 10 native mammals (mostly bats), 17 native reptiles (nine endemic), over 1,100 native plants and an exceptional diversity of invertebrates (Daltry, 2009). The 1980 Wildlife Protection Act mandated the Forestry Department as the principal authority for terrestrial biodiversity, including the protection of globally threatened native species (e.g. the white-breasted thrasher [Ramphocinclus brachyurus sanctaeluciae] and Saint Lucia racer [Erythrolamprus ornatus]),

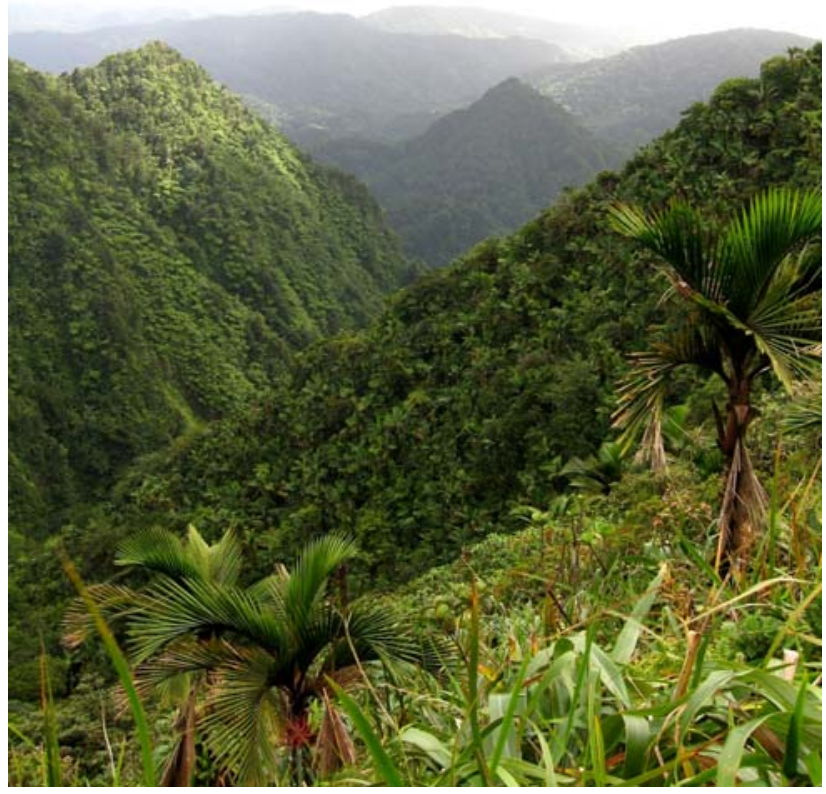

View across the Forest Reserve from Mont Troumassee (C Jenny Daltry, FFI)

ensuring wildlife use is sustainable, and addressing human-wildlife conflict (Daltry, 2009). In 2015, the Department had 82 staff based at its headquarters and at five 'range stations' surrounding the Central Forest Reserve.

Since the plan of Godlet (1970), the Department has been the subject of at least five strategies and plans at the national/sectoral level and six at the Departmental level. These were implemented to varying extents, but none were fully institutionalised and 'owned' by the Department. Managers reported they had not been sufficiently involved in their development, and that implementation had declined when donor support ended. Despite this, in 2014, the Chief Forest Officer (CFO) requested assistance from Fauna \& Flora International (FFI) to develop a new 'management plan' for the Department. The impetus for a new plan was the transfer of the Department in 2012 from the Ministry of Agriculture to the new Ministry of Sustainable Development, Energy, Science and Technology (MSDEST), which required a more strategic approach and better evidence of organisational impact and costeffectiveness. An international consultant (MA) with previous experience of working with the Department was appointed by FFI to support the planning process.

\section{FROM MANAGEMENT PLAN TO AN ORGANISATIONAL CHANGE PROCESS}

The most widely used models for understanding organisational change include the three-stage model of Lewin (1947) and the more recent eight-stage model of Kotter (1996). Biech (2007) provides a useful comparison of these and other change management models. For this study, we used Lewin's (1947) model (unfreezing; movement; refreezing) because it is still 
widely used (Burnes \& Bargal, 2017) and was considered the more straightforward model for introducing organisational change in the Department.

Step 1: 'Unfreezing' - preparing the ground for change, initial problem identification and data collection

\section{Organisational review}

Our starting point was a desktop review of documentation, followed by interviews with senior staff and middle managers, group discussions with staff at all levels, discussions with the Minister and Permanent Secretary at the MSDEST, interviews with representatives of 10 main partners of the Department and an internal workshop attended by all managers and forest officers.

Many of the consultees shared the view that although the history and work of the Department were widely recognised and respected, its influence and status had declined in recent years, leading to concerns about its ability to meet the growing threats to forests and biodiversity. Specific issues included the following:

- $\quad$ Despite its changing role, the strategic approach and institutional culture of the Department were still grounded in forest protection and timber production.

- The Department had sufficient personnel, but they were not deployed as effectively as could be.

- To meet shortfalls in Government funding, the
Department had successfully developed a range of partnerships and secured significant international project funding. Some projects, however, were considered to have been driven more by the needs of donors than the priorities of the Department, which were not always clearly defined.

- $\quad$ Older staff had accumulated extensive experience working under 'Coco' Charles and had benefitted from scholarships for international study. Without these opportunities, younger staff felt less able to take on managerial roles once their leaders had retired and expressed concern about a lack of 'succession planning'.

- Underdeveloped information management was hampering effective planning, decision-making and adaptive management.

- Declining morale was leading to high staff turnover and concerns about staff performance. Reasons given included cuts in budgets and salaries, a freeze on staff recruitment, inadequate resources for work, difficult working conditions in the field and the lack of a clear, shared and motivating direction.

\section{Capacity needs assessment}

In May 2015, 65 of the 82 staff of the Department (including contract forest workers, forest officers, managers, directors and administrative staff) anonymously completed competence-based selfassessment questionnaires, using the methods described

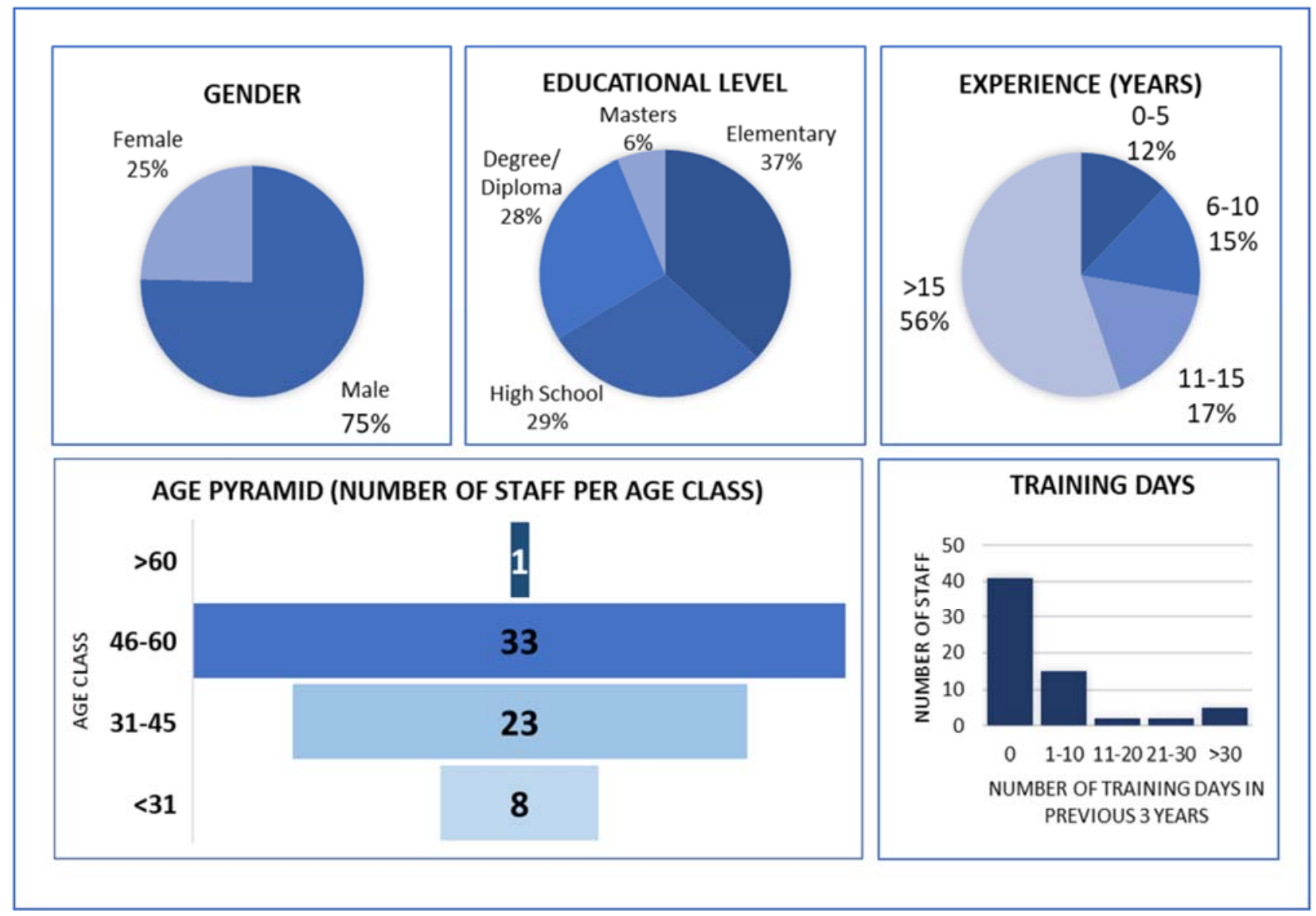

Figure 1. Personnel profile of the Forestry Department (responses from 65 of the 82 staff) 
by Appleton (2016). Figure 1 shows the resulting statistics concerning the workforce. Educational levels varied greatly: while 37 per cent of the staff (all rangers) had only elementary education, most Forest Officers were university or college graduates. Although some staff had benefitted from considerable recent training, most had received no training in the previous three years. The age pyramid showed an ageing staff, mainly a result of Government hiring freezes and of junior staff leaving the Department. These findings supported the widely felt need, especially among the Forest Officers, for change within the Department.

The needs assessment report (Appleton, 2015a) recommended the following priorities for building staff capacity: first aid, safety and security; law enforcement and protection; working with communities; applied conservation biology and conservation management; sustainable forest use and management; protected area and natural resource management planning, monitoring and reporting; information technology; and management, leadership and communication.

The report also recommended moving from donordriven, short-term training, to a more structured, internally driven approach, making better use of existing resources through sharing skills, mentoring, improved internal communications and information management, and formalisation of internal standards and good practice (e.g. through defining core competences for all positions and preparing a new Forestry Officers' handbook). In the absence of international scholarships, the report suggested that staff could be supported to engage in distance learning and that the Department could work with local and regional educational institutions to develop relevant new courses and to adapt current courses to their specific needs.

\section{Unfreezing: lessons learned}

The unfreezing stage involves ensuring both the ability of an organisation to change and the readiness of individuals to change (Lewin, 1947). Several factors contributed to an advanced state of change readiness in the Department.

There was an existing consensus on the need for change. Kotter (1996) highlighted the need to persuade staff to embrace change, but in this case staff at all levels in the Department were ready for change, and this view was supported by many of its partner organisations.

Change was needed, not just planning. Staff realised at an early stage that rather than another management plan, the Department needed more fundamental changes in terms of its function, direction and structure. It was agreed that this required a more comprehensive process of organisational change that should be formalised within a new Strategic Plan for the Department.

Pride and loyalty can support positive attitudes to change in the face of adversity. Despite issues with morale, it was evident that many staff were loyal to the Department and proud of their work. Given the chance, they were motivated to participate and to offer constructive criticism as well as positive ideas for improvement.

Exposure to new values and approaches can be a catalyst for change. The transfer to a new Ministry put the Department outside its 'comfort zone', exposed it to new approaches and values, and required it to prove its worth among a new set of decision makers and peers.

Change needs good leadership. Since the Chief Forest Officer (CFO) was approaching retirement, he delegated management of the process to his Deputy (DCFO) and eventual successor to provide the continuity required. The DCFO had worked his way up through the Department and so had a good understanding of its work and the challenges faced by the staff.

Good communication is vital. Staff and stakeholders had already identified many of the problems and potential solutions among themselves and felt able to share their views with senior managers, who were ready to listen and learn from what they heard.

Constructive consultation supports the change process. The consultative process helped to generate support for the Department and greatly added to the understanding of the staff who were involved. Change is much easier where your friends and peers want you to succeed.

Long-term partnerships can build capacity and support change. Long-term training and mentoring through partnerships with the Durrell Wildlife Conservation Trust (Durrell) and FFI had helped build confidence in external support and establish a cadre of confident and motivated individuals, who were active participants in the change process. The fact that MA was known to the Department, FFI and Durrell, having previously worked on participatory planning in Saint Lucia, helped to overcome a common scepticism of consultants.

Institutional memory can be vital to supplement documented information. Assembling information and documentation was challenging because the Department had no central database and many documents were difficult to trace. Interviews with long-serving staff were essential for understanding past events and processes and for locating important documents.

\section{Step 2: 'Movement' - strategizing, action} planning, implementation and follow up

At a two-day workshop in 2014, senior managers and section leaders identified future directions, policies and priorities for the work of the Department, realigning its approaches, structure and practices to fit its de facto role 
as a natural resource management body. The workshop used four participatory tools:

1. Assessment of external influences through PESTLE (Political, Economic, Social, Technological, Legal, Environmental) Analysis (FME, 2013a).

2. Assessment of the current position of the Department through SWOT (Strengths, Weaknesses, Opportunities, Threats) Analysis (FME, 2013b).

3. Threat assessment, using the Conservation Measures Partnership's taxonomy of threats to biodiversity. (see http://cmp-openstandards.org/ using-os/tools/threats-taxonomy/)

4. Management effectiveness assessment, using the Protected Area Management Effectiveness Tracking Tool (METT) (Stolton \& Dudley, 2016).
The resulting METT score was 55 per cent, close to the global average of 53 per cent calculated by Leverington et al. (2010).

These processes aided participants to develop and agree on a new vision, mission and set of guiding principles for the Department. Participants also agreed to adopt an 'ecosystem approach', using the four main categories of ecosystem service (supporting, provisioning, regulating and cultural) from the Millennium Ecosystem Assessment (2005) to define new strategic directions and policies for the Department. Thirty-six participants at a multi-stakeholder workshop in January 2015 reviewed and amended a first draft of the Strategic Plan.

The Department then prepared a five-year plan specifying actions to be taken for implementing the Strategic Plan, listing collaborating partners, and

Box 1. Main elements of the new Strategic Plan for the Saint Lucia Forestry Department, framed around the delivery of ecosystem services

\section{Vision}

"A healthy natural environment for a healthy and productive nation"

\section{Mission}

"Collaboration and partnership for the preservation and sustainable use of forests, nature and the benefits they provide"

Motto

"La foway et terre se la vie" (forest and land are life)

\section{Strategy 1: Maintaining healthy ecosystems and thriving species.}

The Department will work towards ensuring the conservation of the species and natural communities of Saint Lucia and the integrity of the ecosystems that provide critical services for the country.

\section{Strategy 2: Ensuring sustainable flows of products that support both local economies and biodiversity conserva-} tion.

The Department will work with partners to enable regulated and sustainable use of defined forest areas in support of local livelihoods and economies, while maintaining the biodiversity, recreational and aesthetic values of the forest and the environmental services it provides.

Strategy 3: Protecting water supplies, soils and coastal zones and ensuring resilience to climate change.

The Department will work in partnership with other stakeholders to establish integrated programmes that sustain and enhance the vital regulating services provided by Saint Lucia's forests and other ecosystems. The Department will also work to ensure that Saint Lucia participates in and benefits from global initiatives to address climate change and its impacts.

\section{Strategy 4: Promoting awareness, visitation and cultural enrichment.}

The Department should ensure that all stakeholders are aware of its work and the benefits that it brings to Saint Lucia. It should make parts of the Forest Reserve available for non-motorised access and nature-based recreation and provide basic access facilities. The provision of visitor services should be contracted out, to benefit local communities and the wider economy, and to provide an income to the Department to support monitoring and maintenance.

\section{Strategy 5: Organisational strengthening}

The Department should review and strengthen its organisational structure and working practices, and build the capacity of its personnel to implement Strategies 1-4. 
emphasising what could be done using existing resources and ongoing projects before identifying needs for new additional funding.

Senior managers also realised that implementing the new Strategic Plan would require restructuring of the Department. A new organisational structure, position descriptions and terms of reference were therefore prepared, clustering work teams around each of the five new strategic directions, strengthening central coordination, administration, information management and communication and realigning the forest ranges (operational zones) with natural watershed boundaries.

The final Strategic Plan was approved and launched by the MSDEST in 2015, published online (Saint Lucia Forests and Lands Resources Department, 2015) and distributed to all staff and main stakeholders (see Box 1 for a summary). The Department organised external and internal meetings to explain the plan and its associated changes, including visits to all the forest range (field) stations.

\section{Movement: lessons learned}

A powerful shared vision, mission and guiding principles create a strong sense of ownership and purpose. Visions and missions can have limited utility (Bartkus et al., 2000), but those developed by the Department strongly reflected a shared view among staff and stakeholders that it should be working not only to protect nature and natural systems, but also wherever possible to benefit people. Alongside the new mission and vision, staff decided to retain the Department's existing motto in the Kweole language: "La foway et terre se la vie" (forest and land are life), reflecting both the national culture and the link between nature and human well-being. Feedback from workshop participants led to inclusion of a set of guiding principles to define not only what needed to be done, but also how the Department should approach its work.

Participation is vital, but must take place in the right cultural context. Participation from an early stage enabled most staff to contribute to the process, creating a sense of ownership absent from previous strategies. Because the participants in this case much preferred interpersonal (rather than written) methods, most contributions were verbal, conducted through interviews, workshops and structured and informal discussions. When written questionnaires were used (in the capacity needs assessment), they were completed by individuals working in facilitated groups. This mainly oral and often informal process may not be appropriate or effective in all countries and cultures, but illustrates the importance of matching the methods to the cultural context.

High-level support is required, but ideally with a light touch. The Minister and Permanent Secretary were highly supportive of this project, followed its progress,

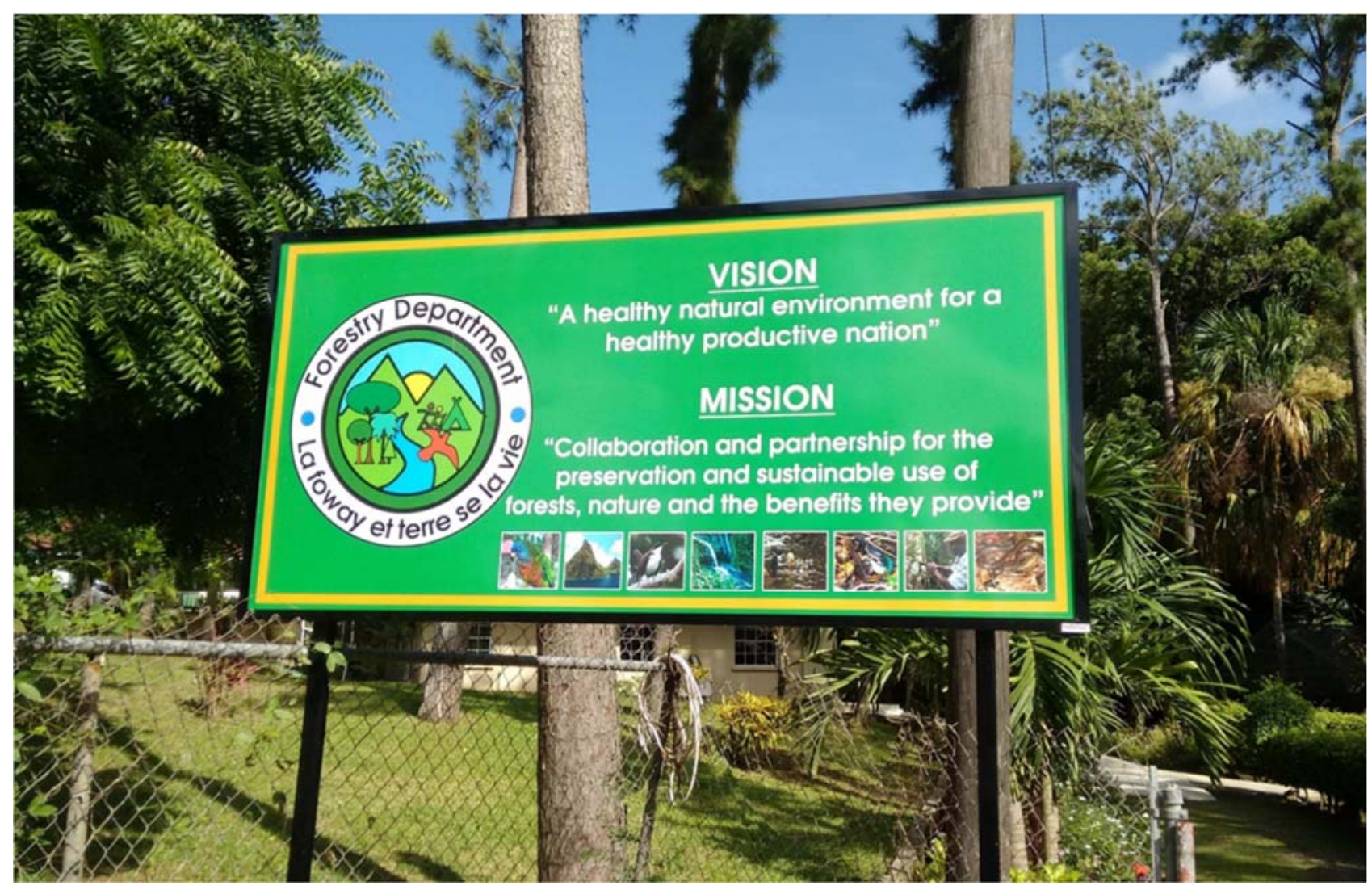

Figure 2. The new vision and mission displayed at the entrance to the Forestry Department headquarters (C) Jenny Daltry, FFI). 


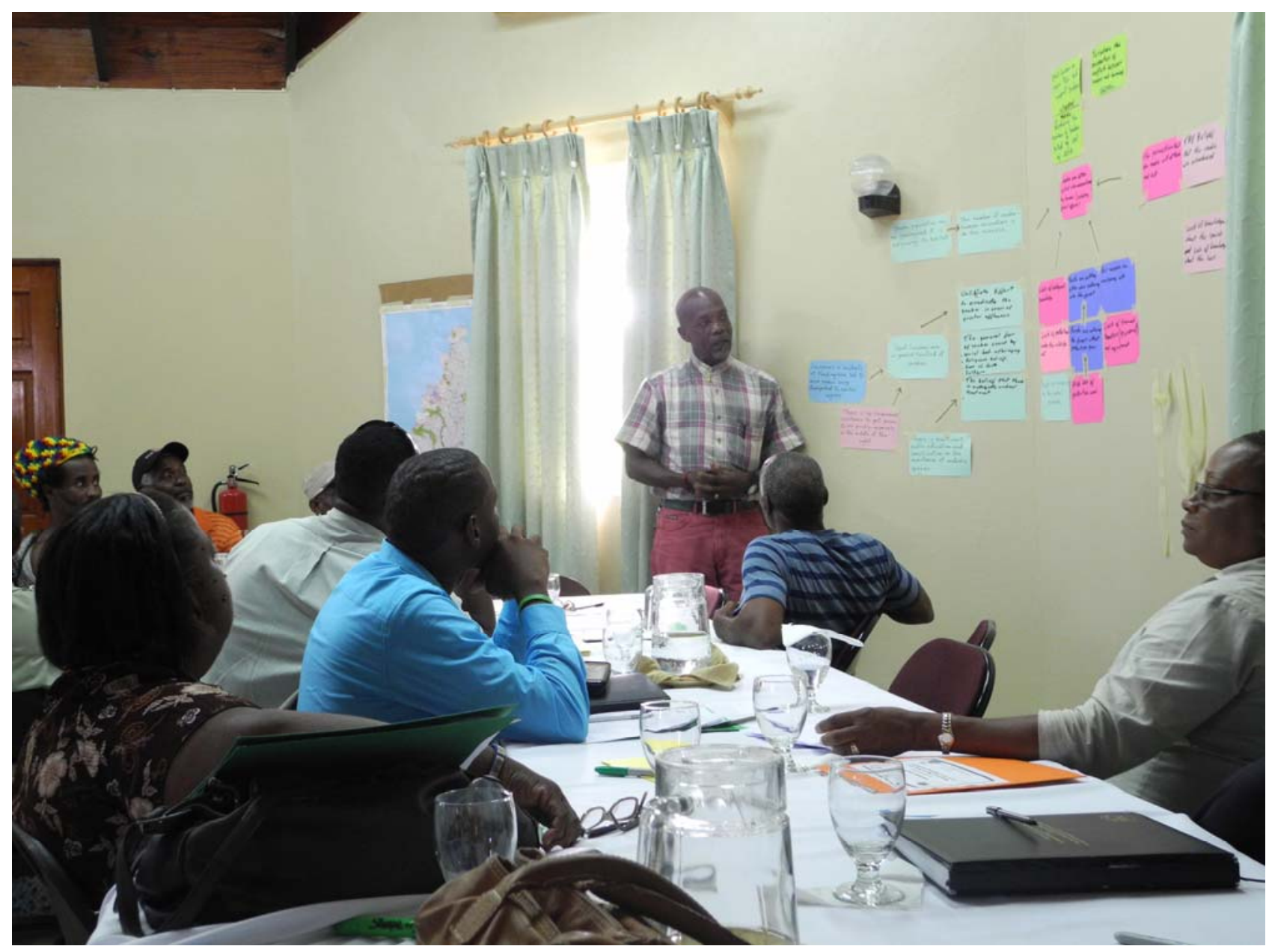

Planning workshop with Forestry Department staff and other stakeholders (@ Jenny Daltry, FFI)

and were accessible and responsive throughout, but they also clearly delegated direction and supervision of the process to the CFO and DCFO. This approach was conducive to building ownership and confidence at Departmental level.

Strategic planning can make problematic decisions easier. The Department had long been encouraged by the Government to initiate the complex process of contracting out management of visitor access in the Central Forest Reserve. The planning process helped prioritise the allocation of the Department's staff and resources on its core responsibilities, making this decision more logical and therefore easier.

People prefer short documents. All those consulted agreed that the strategic plan should be clearly presented and not too long. The final document had 50 pages in total, and the main text covered 30 pages.

'Quick wins' are important. The following examples from the initial stages of implementation in 2015 were 'quick wins' as recommended by Kotter (1996) - priority actions that could be undertaken without delay, demonstrating rapid adoption of the new plan:
- Redecoration of the Department office and installation of prominent signs showing the new vision and mission (Figure 2). This promoted the Department's new approach and provided a visible indication of a 'fresh start', helping to boost staff interest and morale.

- $\quad$ Rapid reorganisation of the forest range areas to coincide with watersheds, providing more logical operational zones that reflect the new ecosystembased approach.

- $\quad$ Rapid engagement of a specialist consultant to plan the contracting out of visitor services in the Forest Reserve.

- $\quad$ Clarifying to staff how several ongoing activities that appear in the new plan (e.g. tree planting to stabilise eroded slopes areas and removal of invasive alien species from offshore islands) contribute to the overall goals of the Department.

- Launching of new initiatives already in the pipeline, such as the GEF-funded 'Iyanola Project' to protect and rehabilitate dry forests in northeast Saint Lucia (identified as a priority in the strategic plan). 


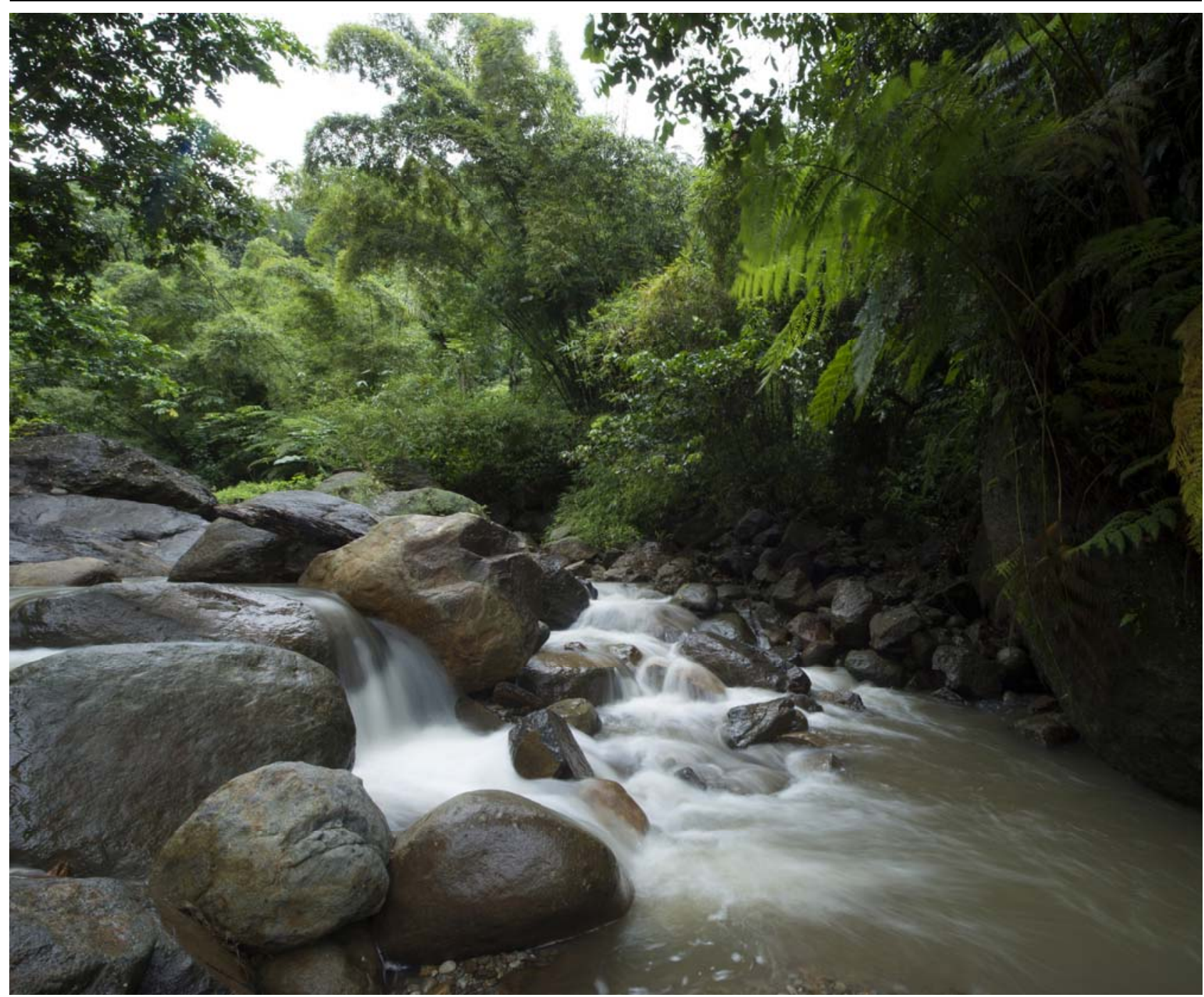

The Forest Reserve plays a vital role in water management (@ Jeremy Holden FFI)

Step 3: 'Refreezing' - institutionalisation of the change, assessment of consequences, follow up and monitoring, learning from the process

Overall, the adoption and implementation of the changes proposed in the new plan have been remarkably swift. A contributing factor may have been that in a small country, lines of communication are quite short and agreed changes can be quickly communicated and realised at both central and protected area levels.

Reorganisation of staffing structures and responsibilities has been completed and, at the time of writing, work planning and reporting is increasingly based on the fiveyear action plan.

By highlighting the diverse functions of the Department, the Strategic Plan has enabled talented staff qualified in subjects other than forestry to be retained and promoted, and has helped the Department to secure Government support for retired forest officers to train current staff and for sending some staff for training overseas.

The process has also helped the Department manage its unexpected transfer back to the Ministry of Agriculture in 2016, which not only accepted and welcomed the Strategic Plan, but adopted a similar approach for its own new strategy. There have been other unexpected consequences. For example, the Ministry of Public Service has acknowledged the Strategic Plan and the reorganisation of the Department as a model for upgrading and modernising public service organisations, while the Productivity Council of the Ministry of Finance has agreed to use the Department to pilot public service productivity reform.

\section{Refreezing: lessons learned}

Effective internal change can help an organisation adapt to externally driven change. The changes are enabling the Department to be well prepared to address, benefit from and even positively influence ongoing political and administrative changes in Saint Lucia.

The change process generates new capacity development needs. The process identified many specific needs for capacity development. Implementation of the Strategic Plan has made these needs more urgent and highlighted needs that had not previously been recognised. 
It should not be assumed that all staff will immediately understand new strategic directions. Despite efforts to explain the new plan, some staff have not yet fully understood the 'ecosystem approach' that underpins it.

The existence of a new plan does not automatically generate the resources needed to implement it. The new plan has not yet led to any direct budget increases from the Government, and full adoption is hampered by lack of support for some key elements, notably training and the establishment of an IT network and management information system. However, government officials are now much more aware of the Department's objectives and priorities, and regularly inform managers about suitable opportunities for projects and funding. Department staff also now use the Strategic Plan as a basis for new grant proposals.

Indicators should have been included in the Strategy. The Ministry of Public Service recently requested identification of Key Performance Indicators (KPIs) across the Government. These were not included in the new Strategy, but the Department is now working with the Productivity Council to identify KPIs for the goals and targets of the Strategic Plan. This should lead to improvements in both internal and external reporting.

\section{DISCUSSION}

Kuipers et al. (2013) note that while rapid, top-down approaches to organisational change tend to prevail in US/Anglo-centric countries, bottom-up approaches are more widely adopted in countries with more consensual systems of governance. Rusaw (2007) characterised four approaches to change in public organisations: a) Planned, rational approaches to select best interventions and implement long-term, comprehensive change (e.g. through strategic planning); b) Incremental models, that make minor changes in existing systems to achieve limited but tangible and quick results; c) Pluralistic models, that cultivate multiple stakeholder input, resources, and commitment to resolving local social or economic problems; and d) Individual models, such as training and development programmes.

The change process in Saint Lucia was multifaceted, incorporating all these approaches:

- 'Top down': through the new requirements of the Ministry, imposed financial constraints and a move towards more accountability in the public sector.

- $\quad$ Middle out': through the desire of senior and middle managers to address shortcomings in the organisation and the need for succession planning.

- 'Bottom up': in response to the impacts of declining morale and underperformance.
- $\quad$ Outside in': through encouragement from the Department's partners for improvements in its capacity and status.

- $\quad$ 'Inside out': through the need for the Department to influence and engage in sectors and activities related to its evolving and expanding role.

This situation is probably quite rare, but illustrates a set of conditions under which the state of change readiness, as identified in the section 'Unfreezing: lessons learned', was so advanced that the process was widely supported and to some extent spontaneous. These lessons may assist other organisations in establishing an enabling environment that would make their change process easier and more constructive. Strategic planning is defined by Bryson (2011) as "a deliberate, disciplined approach to producing fundamental decisions and actions that shape and guide what an organization is and what it does". However, its role and function are not generally well defined in the protected area sector, where more emphasis is placed on site-based management planning and where planning guidance tends to focus on rational identification of what is needed for that specific protected area, with less attention paid to establishing the organisational enabling environment required for effective plan implementation. A notable exception is Amend et al. (2003).

Kohl and McCool (2016) were highly critical of strategic planning in the natural and cultural heritage sector, highlighting the widespread perception that most plans are 'left on the shelf' and largely blaming 'rational comprehensive' approaches adopted by managers, donors and consultants. They advocated adoption of 'holistic planning', defined as "a facilitated, continuous dialogue with heritage area constituencies designed eventually to construct a consensus about a desired evolving future", and encouraged planners to acknowledge individual, collective and cultural factors, alongside the rational and technical considerations that normally dominate planning and plans.

In the case of Saint Lucia, the original intent to produce a site-based management plan was superseded by a strategic planning and change process that has embraced many of the principles of the holistic approach advocated by Kohl and McCool (2016), but whose end-product has been a concise, but conventionally structured plan designed to be accessible to staff, partners and government officials. We suggest that prioritising participatory strategic planning at the organisational level can help establish the institutional and individual capacities and 'enabling environment' that will create more relevant and sustainable site-based plans (reflecting Kotter's, 1996, seventh stage: 'Build on the Change'). 
Morales-Hidalgo et al. (2015), using data from FAO (2015), report that 17 per cent of the world's forests are in legally established protected areas, accounting for 651 million ha. Globally, forestry-related authorities are responsible for more than 19,400 protected areas, at least 10.5 per cent of those in the World Database on Protected Areas that identify a managing authority. The change process in Saint Lucia demonstrates how a forestry authority responsible for protected areas has successfully adapted to changing policies, priorities and environmental conditions by responding to demands for change that were internal as well as external, and by realigning its strategic directions and structure to reflect its evolving role.

The need for organisational capacity in the conservation NGO sector is attracting increasing attention and support (e.g. through the website capacityforconservation.org). Much less attention is being given to addressing the specific needs and challenges facing government organisations (which manage most of the world's protected areas) if they are to meet global expectations for biodiversity conservation and protected area management (Appleton, 2015b; WCPA Capacity Development Thematic Group, 2017). We encourage further studies, publications and practical initiatives to understand and address this issue.

\section{ACKNOWLEDGEMENTS}

The work described in this paper was funded by the Saint Lucia Forestry Department, Fauna \& Flora International, Halcyon Land and Sea (supported by Arcadia, a charitable fund of Lisbet Rausing and Peter Baldwin), and (specifically for the capacity needs assessment in Step 1) the IUCN BIOPAMA Programme. The authors thank all the many staff and stakeholders who contributed, the former Minister of Sustainable Development, Energy, Science and Technology Dr James Louis Fletcher, former Permanent Secretary at the MSDEST Sylvester Clauzel, Chief Forest Officer (retd.) Michael Bobb, Deputy Chief Forest Officers Alfred Prospere and Alwin Dornelly, Bishnu Tulsie (Director, Saint Lucia National Trust), Matthew Morton (Eastern Caribbean Manager, Durrell Wildlife Conservation Trust) and James Crockett (Responsible Tourism Specialist).

The authors are also grateful to the two anonymous reviewers for their constructive comments that greatly helped improve this manuscript.

\section{ENDNOTES}

${ }^{1}$ Analysis conducted on www.protectedplanet.net on 28/04/2017 using the following search terms: forest, forêt, forst, silv, sylv, mets, bosc, bosq, sumar, skog and hutan.

\section{ABOUT THE AUTHORS}

Michael Appleton is Director of Protected Area Management for Global Wildlife Conservation (since January 2017) and Vice-Chair for Capacity Development for the IUCN World Commission on Protected Areas. He was contracted as a consultant by Fauna \& Flora International to facilitate the work described in this paper between 2014 and 2016.

Adams Toussaint is Chief Forest Officer for the Saint Lucia Forestry Department and an authority on ornithology in the country. He oversaw the strategic planning and organisational change processes described in this paper.

Jennifer Daltry is Senior Conservation Biologist and Head of Caribbean at Fauna \& Flora International. Since she started working in Saint Lucia in 2000, Dr Daltry's work has focused on the recovery of endangered species, habitat restoration and tackling threats from invasive alien species and unsustainable exploitation.

\section{REFERENCES}

Amend, S., Giraldo, A., Oltremari, J., Sánchez, R., Valerio, V. and Verena, E. (2003). Management Plans: Concepts and Proposals. Parques Nacionales y Conservación Ambiental No. 11. Panama.

Anon (2014). Performance Improvement Framework Review: Department of Conservation. Wellington, New Zealand: State Services Commission, the Treasury, and the Department of the Prime Minister and Cabinet. www.ssc.govt.nz/sites/all/files/pif-review-doc-july14.PDF

Appleton, M.R. (2015a). Assessment of capacity development needs of conservation staff in Saint Lucia. Unpublished report to IUCN Biodiversity and Protected Areas Management Programme. Gland, Switzerland: IUCN.

Appleton, M.R. (2015b). Capacity Development Needs and Priorities for Nature Conservation in South-Eastern Europe. Gland, Switzerland and Belgrade, Serbia: IUCN and IUCN Regional Office for Eastern Europe and Central Asia.

Appleton, M.R. (2016). A Global Register of Competences for Protected Area Practitioners. Gland, Switzerland: IUCN.

Bartkus, B., Glassman, M. and McAfee, R. B. (2000). Mission statements: are they smoke and mirrors? Business Horizons, 43(6), 6-23. doi.org/10.1016/S0007-6813(00) 80018-X

Biech, E. (2007). Thriving Through Change: A Leader's Practical Guide to Change Mastery. Alexandria, Virginia, USA: ASTD Press.

Bryson, J.M. (2011). Strategic Planning for Public and Nonprofit Organizations. Fourth Edition. San Francisco, USA: Jossey-Bass.

Burnes, B. and Bargal, D. (2017). Kurt Lewin: 70 Years on. Journal of Change Management, 17 (2), 91-100. doi.org/10.1080/14697017.2017.1299371

Colwell, R., Avery, S., Berger, J., Davis, G.E., Hamilton, H., Lovejoy, T., Machlis, G., Malcom, S., McMullen, A., Novacek, M., Roberts, R.J. and Tapia, R. (2014). Revisiting Leopold: Resource Stewardship in the National Parks. 
Washington, D.C., USA: National Park System Advisory Board Science Committee.

Convention on Biological Diversity (2010). The Strategic Plan for Biodiversity 2011-2020 and the Aichi Biodiversity Targets. Montreal, Canada: Convention on Biological Diversity. www.cbd.int/doc/decisions/cop-10/cop-10-dec02-en.pdf

Daltry, J.C. (2009). Biodiversity Assessment of Saint Lucia's Forests, with Management Recommendations. Technical Report No. 10 to the National Forest Demarcation and Bio -Physical Resource Inventory Project. Helsinki, Finland: FCG International Ltd.

Dawson, P. (2003). Understanding Organizational Change: The Contemporary Experience of People at Work. London, UK: Sage.

Durst, P., Brown, C., Broadhead, J., Suzuki, R., Leslie, R. and Inoguchi, A. (eds) (2008). Re-inventing Forestry Agencies: Experiences of Institutional Restructuring in Asia and the Pacific. Bangkok, Thailand: UN Food and Agriculture Organization (FAO).

FAO - Food and Agriculture Organization (2015). Global Forest Resources Assessment 2015: How Are the World's Forests Changing? Rome, Italy: FAO.

FME (2013a). PESTLE Analysis: strategy skills. Free Management Ebooks. www.free-managementebooks.com/dldebk-pdf/fme-pestle-analysis.pdf

FME (2013b). SWOT Analysis: strategy skills. Free Management Ebooks. www.free-managementebooks.com/dldebk-pdf/fme-swot-analysis.pdf

Godlet, I. (1970). Forest Work Plan 1970-1980. Castries, Saint Lucia: Ministry of Agriculture.

IUCN and WCPA - World Commission on Protected Areas (2016). IUCN Green List of Protected and Conserved Areas: Standard, Version 1.0. Gland, Switzerland: IUCN.

Kohl, J. and McCool, S. (2016). The Future has Other Plans. Planning Holistically to Conserve Natural and Cultural Heritage. Golden Colorado, USA: Fulcrum Publishing.

Kotter, J.P. (1996). Leading Change. Boston, USA: Harvard Business School Press.

Kuipers, B.S., Higgs, M.J., Kickert, W.J.M., Tummers, L.G, Grandia, J. and van der Voet, J. (2013). The management of change in public organisations: A literature review. Public Administration, 92, 1-20. doi.org/10.1111/ padm.12040
Leverington, F., Costa, K., Courrau, J., Pavese, H., Nolte, C., Marr, M., Coad, L., Burgess, N., Bomhard, B. and Hockings, M. (2010). Management Effectiveness Evaluation in Protected Areas - A Global Study. Second edition. Brisbane, Australia: University of Queensland.

Lewin, K. (1947). Frontiers in group dynamics. In D. Cartwright (Ed.), Field Theory in Social Science. London, UK: Social Science Paperbacks.

Millennium Ecosystem Assessment (2005). Ecosystems and Human Well-Being. Washington, D.C, USA: Island Press.

Morales-Hidalgo, D., Oswalt, S.N. and Somanatan, E. (2015). Status and trends in global primary forest, protected areas, and areas designated for conservation of biodiversity from the Global Forest Resources Assessment 2015. Forest Ecology and Management, 352, 68-77. doi.org/10.1016/j.foreco.2015.06.011

Pick, D., Teo, S., Tummers, L. and Newton, C. (2015). Advancing knowledge on organizational change and public -sector work. Journal of Organizational Change Management, 28 (4). doi.org/10.1108/JOCM-06-20150088

Rusaw, A.C. (2007). Changing public organizations: four approaches. International Journal of Public Administration, 30 (3), 347-361. doi.org/10.1080/01900690601117853

Saint Lucia Forests and Lands Resources Department (2015). Strategy 2015-2025. Union, Saint Lucia: Saint Lucia Forestry Department. www.malff.com/images/stories/ forestry/resources/Forests\%20and\%20Lands\% 20Resources\%20Department\%20Strategy\%202015-2025\% 20ver\%205.pdf

Sandwith, T., Enkerlin, E., MacKinnon, K., Allen, D., Andrade, A., Badman, T., Brooks, T., Bueno, P., Campbell, K., Ervin, J., Laffoley, D., Hay-Edie, T., Hockings, M., Johansson, S., Keenleyside, K., Langhammer, P., Mueller, E., Smith, T., Vierros, M., Welling, L., Woodley, S. and Dudley, N. (2014). The Promise of Sydney: An editorial essay. Parks, 20 (1), 7-18.

Spathelf, P. (ed.) (2010). Sustainable Forest Management in a Changing World: A European Perspective. New York, USA: Springer. doi.org/10.1007/978-90-481-3301-7

Stolton, S. and Dudley, N. (2016). METT Handbook: A Guide to Using the Management Effectiveness Tracking Tool (METT). Woking, UK: WWF-UK. 


\section{RESUMEN}

Si bien las expectativas mundiales acerca de los servicios que deben prestar las áreas protegidas están evolucionando (por ejemplo, a través de los Objetivos de Aichi y los Objetivos de Desarrollo Sostenible de las Naciones Unidas), poca atención se ha prestado a cómo pueden las dependencias gubernamentales que se ocupan de las áreas protegidas adaptar y mejorar su desempeño en consecuencia. El ámbito de competencia del Departamento Forestal de Santa Lucía se ha ido ampliando progresivamente desde la producción forestal hasta, entre otras cosas, la gestión de áreas protegidas, investigación y conservación de la vida silvestre, gestión de cuencas hidrográficas, turismo y educación ambiental. En 2014, en respuesta a un consenso generalizado sobre la necesidad de actualizar sus métodos de trabajo, el Departamento inició un proceso participativo de planificación estratégica y cambio institucional, que comprende: (1) Análisis organizativo y evaluación de las necesidades en materia de capacitación; (2) Desarrollo de un nuevo plan estratégico y la correspondiente reestructuración de la organización; y (3) Institucionalización del plan. Este proceso positivo en general proporciona lecciones importantes con una aplicación potencialmente más amplia sobre "predisposición al cambio", liderazgo, capacidad, comunicación, participación y el valor de "logros rápidos”. Aunque es necesario seguir trabajando en el desarrollo de capacidades y la institucionalización total de los cambios, el Departamento Forestal puede ahora articular mejor sus funciones y necesidades y garantizar la conservación a largo plazo y el uso sostenible de la biodiversidad de importancia mundial de Santa Lucía, tanto dentro como fuera de sus áreas protegidas. Hacemos hincapié en la necesidad de contar con más estudios e iniciativas sobre cambios organizativos en las dependencias gubernamentales responsables de las áreas protegidas y la conservación de la biodiversidad.

\section{RÉSUMÉ}

Alors que les attentes, au niveau mondial, liées aux aires protégées sont en train d'évoluer (par exemple, les Objectifs d'Aichi et les Objectifs de développement durable des Nations Unies), peu d'attention a été accordée à la manière dont les agences gouvernementales peuvent adapter et améliorer leurs performances en conséquence. Les attributions du Département des Forêts de Sainte-Lucie se sont progressivement étendues de la production forestière à la gestion des aires protégées, à la recherche et à la conservation de la faune, à la gestion des bassins versants, au tourisme et à l'éducation environnementale. En 2014, en réponse à un large consensus sur la nécessité de mettre à jour ses méthodes de travail, le Ministère a lancé un processus participatif de planification stratégique et de changement organisationnel comprenant: 1) un examen organisationnel et une évaluation des besoins en capacités ; 2) le développement d'un nouveau plan stratégique et la restructuration correspondante de l'organisation; et (3) l'institutionnalisation du plan. Ce processus, généralement couronné de succès, fournit des leçons importantes ayant potentiellement une application plus large sur l'adaptation au changement, le leadership, les compétences, la communication, la participation et l'intérêt de sécuriser rapidement des 'petits succès'. Bien qu'il soit nécessaire de renforcer encore les capacités et d’institutionnaliser pleinement les changements, le Département des Forêts est désormais mieux à même d'articuler ses rôles et ses besoins et d'assurer la conservation et l'utilisation durable de la diversité biologique de Sainte-Lucie, que ce soit au sein de ses aires protégées ou non. Nous préconisons la mise en place d'études et d'initiatives nouvelles visant un changement organisationnel dans les agences gouvernementales responsables des aires protégées et de la conservation de la biodiversité. 